\title{
Making Your Memory Mine: Marie de France and the Adventures of the Bretons ${ }^{1}$
}

\author{
Jeffrey S. Longard \\ University of Alberta, Canada
}

\section{Introduction}

The twelfth-century poet Marie de France, a seminal figure in the genesis and development of French literature, saw herself primarily as a translator. This is not surprising, since the great writers of the day, from Chrétien de Troyes to Geoffrey Chaucer, participated in the medieval "wave of translations" (Kinoshita and McCracken 8) that took first as its task the translation of Latin classics into the vernacular, and then increasingly the translation or re-creation of oriental works and of European stories and legends. Unlike the status of translation in much of recent history, where it is held to be derivative and secondary (Venuti 7), in the Middle Ages it was considered part of the creative network of intercultural and interlinguistic exchange (Warren 51-2). The translator, far from being an invisible servant of the original text, became its authoritative voice, and the purpose of the translation was in the end not to supplement the original but to "substitute itself for its source and efface the presence of that source" (Copeland 202).

Very little is known about Marie. She was probably from Île-de-France, but may have lived in England, connected with the Anglo-Norman court of Henri II and Aliénor d'Aquitaine. She translated a collection of fables from an Anglo-Saxon original into French sometime in the latter half of the twelfth century, and later (around 1190) translated from a Latin text an account of a descent into Purgatory. Her first work, probably composed soon after 1165, was a collection of twelve tales of Breton, Welsh and other unspecified origin, the Lais, which she transformed into octosyllabic French verse (Kinoshita and McCracken 1-5, Paris 295). From this it can be seen that her education, general knowledge and linguistic ability must have been extensive, and furthermore, that her creativity was fertile and capable. She was one of the pioneers among medieval European writers to turn from the reworking of Latin classics to vernacular stories, and with the Lais she likely assumed the added challenge of transforming oral poetry of one language into written poetry of another. Her self-imposed goal was to preserve for posterity the adventures and romances embodied in a vanishing genre, the old Breton lais as she claimed to have heard them recounted by minstrels (Prologue line 40). That she succeeded in her task is evidenced by the survival and popularity of her Lais for more than eight hundred years; that she perhaps succeeded too well is suggested by the fact

\footnotetext{
1 The first version of this article was presented in May 2015 as a doctoral candidacy comprehensive examination, and a second version was presented in September 2015 at the conference "Translation and Memory", the 13th annual St Jerome's Day Conference at the University of Alberta. I am indebted to conference participants, especially Dr. Anne Malena and Dr. Lynn Penrod, for their insightful comments. As the article neared completion, I was so fortunate as to receive further suggestions from Professor Malena, as well as a wealth of helpful critiques, in particular regarding recent work on Marie de France and colonialism, from an anonymous reviewer.

This research was supported in part by the Social Sciences and Humanities Research Council of Canada and by the University of Alberta, to whom I express my sincere gratitude.
} 
that, within a century of her lifetime and perhaps due in some measure to her work, the Breton lais were exclusively a French form of literature, and what might have been the original form, linguistic structure and cultural content in Breton has been, ever since that time, reduced to a matter of conjecture.

This raises questions about the relationship between translation and cultural autonomy. To what extent does translation simply make an interlingual copy of a work as opposed to so far removing it from its own context that it can continue to exist only in its adoptive sphere? In what ways are translations acts of respect and homage, in what ways acts of pillage and aggrandizement? Did Marie de France rescue, as a sort of early ethnographer, aspects of the old Breton culture and ensure their enduring place in human memory, or did she colonize them for literary, political, and cultural gain?

How translation elevates or diminishes its source, how it masters it or is itself subsumed, is not a new discussion. Translators have been reflecting on the practical, artistic and ethical implications of their craft in a more or less ad hoc fashion for centuries; in recent decades the field of translation studies has attempted to discover underlying unified principles and to develop a theoretical model of translation. Although this remains problematic, approaches that coherently examine and evaluate the translation process are of great value in broaching questions such as those posed above. All translation involves an act of desire and an act of invasion. Nevertheless, because translation creates a sort of reproduction of the desired artifact rather than its removal, it is not a straightforward question of theft. The ethical aspect of the process comes to the fore when we examine how a work is incorporated into the receiving culture, and in what ways that incorporation pays tribute to the source.

The issue of the relationship of the original Breton lais to the collection by Marie de France is a thorny one in both literary and cultural terms, and in the following pages I wish to examine Marie's choice of material, the passage from oral Breton poetry to written French, the place of the Lais in Anglo-Norman society, and the implications of the transformation for the question of translation and memory. Since linguistic translation cannot be separated from cultural (Asad 142), translation involves the collusion or the collision of peoples and their ideas, and evokes comprehensive ethical reflection. I will argue that it is Marie's approach to the translation process that produces the lively and at times unsettling heterogeneity of the final result: Marie neither privileges the exotic aspects of Breton culture, nor does she polish them into a domesticated AngloNorman symmetry. Rather, by importing wholesale into her Lais the Breton worldview and setting it in company with the feudal, christianized and courtly England of her day, as though these disparate elements actually belonged together in all their stark incoherence, she adopts the Breton tales as her own heritage. In doing this, she both exploits the memory of the Bretons and valorizes it for centuries to come. 


\section{Methodology}

It has become fashionable when discussing translation to bounce endlessly against the binaries of "foreignization" versus "domestication" or word-for-word as opposed to sense-for-sense. We do this perhaps without ever realizing that we are entering the debate in the middle, both historically and philosophically. The debate goes back to Cicero, through Jerome and the Church Fathers and Dryden among so many others, and I would contend that in the modern era we await anyone who can articulate the problem better than Schleiermacher has already done. Moreover, we assume what has yet to be demonstrated, namely, that we are able to define word, sense and reality and the relationship of these elements. I do not advocate discarding the notions of domestication/foreignization, literal/paraphrase, adaptation, and so on; it is not unhelpful, and at times it is virtually necessary, to discuss translation in these terms. The problem rather lies in our tendency to reduce the analysis to binaries, to gloss over the historical perspective, and to fail to acknowledge and qualify our assumptions; for these reasons the discussion is almost always oversimplified and far less precise than it purports to be. It is not to replace one limited system with another, but to add depth and nuance to the analysis, that I propose in this article to operate within the framework of another way of looking at translation, which is as a process of the transformation of an artifact within the context of the involved cultures. George Steiner's descriptive model, which he calls the "Hermeneutic Motion", analyzes translation as a four-fold process. The first stage is initiative trust, or the belief that the source is worth obtaining and bringing back; followed by aggression, or invasion of the linguistic and cultural territory of the desired artifact; then incorporation, the importing of the object into the receiving culture; and finally restitution, wherein the translation contributes to the status and understanding of the source text (312-319). Steiner concludes that the issue of "fidelity" is not resolved by attempting to locate the translation on the spectrum of word-for-word versus sense-for-sense but in an evaluation of an ethical and economic fair exchange (318). This approach offers particular insight into Marie's translation project as cultural transfer and enables an overall assessment even when, as in our case, the source texts are not extant for comparison.

\section{Latin, French and Breton: The Choice of Material}

The latter half of the twelfth century in France and England was a time when relative peace and prosperity followed upon great changes - the Crusades, the Norman invasion of England, the rise and spread of the feudal system, the growing prominence of women in public and scholarly affairs, the unprecedented popularity of Provençal love poetry — and an educated elite had leisure to indulge in creative activity (Hoepffner 8-15; Rumble xiv, xix). This expressed itself in a blossoming of literary production; the great writers of what has been called the "Renaissance of the twelfth century" would mark western literature for centuries to come. A vast number of significant translations as well as original works were appearing in French, works that celebrated the rediscovery of classical learning, incorporated foreign concepts, and established all-new subjects for exploration 
and new genres in which to house them. The richness of twelfth-century life with its harmonies, intersections and collisions of significant trends, could not but imprint itself upon contemporary art.

Marie was among the first to turn toward the "matter of Britain." Previously, mentions of the Breton legends and the minstrels that recounted them were scarce. Wace contains the earliest references to the travelling minstrels and their entertainments, predating Marie's Lais by perhaps a decade, but he was somewhat critical of their tendency to sensationalize their tales (lines 9787-9798), while Thomas d'Angleterre claims to have chosen his version of Tristan from the best information found among the professional minstrels (Gottfried Tristan/Thomas 338). Besides the twelve lais of Marie, there are a handful of other lais from the period (none earlier than Marie's, and all in French ${ }^{2}$ ), which show thematic connections to Marie's, especially to Lanval and Eliduc. Hoepffner argues that these thematic elements, drawn perhaps from a common source, usually depend on Marie's version of them (e.g. 130, 131, 140); O'Hara Tobin, in her detailed study of the anonymous lais, comes to the same conclusion (e.g. 21, 32, 57). There is, then, no extant French source on which Marie might have depended. Consequently, though it is not possible to prove beyond any doubt that Marie created the French lai or was the first to exploit the Breton genre in translation, it is more difficult to make a convincing case for the opposing position; virtually everything that is known about the lais as French poetry is found in Marie's own work. We may tentatively accept her claim, then, that she drew directly upon Celtic sources; what the actual form and content of those sources may have been will be examined in greater detail below.

What caused Marie to look in the direction of the Breton legends for the sources of her project; what, in Steiner's terms, provoked her first movement of initiative trust? In the Prologue, Marie sets out her reasons. Her primary, and most general, motivation was to discipline herself through study and hard work, and to add to the sum of knowledge by expounding the wisdom of earlier times, which is the responsibility of those to whom God has given intelligence and eloquence (lines 1-27). More particularly, she had at first determined to translate something from Latin, but since so many had already done so, there could be little renown for her in imitating the same process. This is her secondary motivation, to make a name for herself (lines 28-32). She then thought of the many lais that she had heard, knowing that those who had composed and sung them had wanted to perpetuate the stories behind them. She did not wish to see them fade from memory, so she wrote them down in verse form (lines 33-42); this memorial is her tertiary and fully focused motivation.

By choosing to translate from a vernacular language, Marie uses the established medieval position of the translator/writer, who was the authoritative voice of ancient knowledge for a contemporary society, to assign to the Breton lais a legitimate space in the translator's library. Through this act she bestows on the voice of the Bretons a canonical status equal to the Latin classics (Copeland 118). Yet it cannot be forgotten that these two languages, French and Breton,

\footnotetext{
${ }^{2}$ Early collections of the lais in other languages (Old Norse and Middle English) constitute no real independent witness, since they were avowed translations of their French models and were close to them both formally and temporally.
} 
were in a very unequal position (see Asad 156-8), with French the language of the conquerors and their court, and Breton that of a thrice-conquered minority — the Normans were but the latest on a list that included the Saxons and before them the Romans. This gave Marie power over the transfer that she would never have had if dealing with a Latin source.

Breton and French were likewise unequal in their relationship to Latin. The medieval period was characterized by what Stierle (56) calls "vertical translation", the hierarchical transmission of the Latin heritage to those who saw themselves as its legitimate successors, whose task it was to interpret and amplify the original. While early Roman (and later, Renaissance) translation was "horizontal", the acquisition of material from a foreign language or culture regarded as equal or even superior, medieval translators saw their role not only as inheriting but as actually improving upon the source, expanding and refining its meaning. It is surely this to which Marie de France refers when she says:

It was the custom of the ancients,

as Priscian attests,

in the books which they wrote in olden times,

to speak quite obscurely

for the sake of those who were to come

and who would be constrained to study them,

so that they might be able to comment on them

and contribute more to their meaning.

The philosophers were aware of this fact,

they themselves understood it,

that the more time advanced,

the more people would be sophisticated in their understanding

and the more they would know how to avoid

going beyond the intended sense in what was written. (Lais, Prologue lines 9-22) ${ }^{3}$

Medieval translation, then, was much more than language transfer. The transformation of knowledge linguistically, the transmigration of knowledge geographically, the accumulation of knowledge temporally and the refinement of knowledge rhetorically were all aspects of the medieval writer's consciousness, the awareness of participation in translatio studii, the movement of knowledge from one time, place, language or culture to another. Chrétien de Troyes summarizes this expansive view of translation in Cligès lines 30-39:

Our books have taught us this, that Greece held of gallantry

\footnotetext{
${ }^{3} \mathrm{My}$ translation of "Custume fu as anciëns, / ceo testimoine Presciëns, / es livres que jadis faiseient/assez. oscurement diseient/pur cels ki a venir esteient/e ki aprendre les deveient, / que peüssent gloser la letre/e de lur sen le surplus metre. / Li philesophe le saveient, /par els meïsmes l'entendeient, / cum plus trespassereit li tens, /plus serreient sutil de sens/ e plus se savreient guarder/ de ceo qu'i ert, a trespasser." All translations in this article, except where noted, are my own.
} 
and of learning the first rank.

Then gallantry came to Rome,

as did the pinnacle of learning,

which now has come into France.

May God grant that it be preserved within her

and that our land may embellish it

so that never from France may depart

the honour that has come to rest here. ${ }^{4}$

Chrétien and others of his day saw the transfer of knowledge from East to West and from past to present as an inevitable socio-historical phenomenon in which linguistic translation, from Greek through Latin to French, must play an integral part. Formerly, throughout late antiquity and the early medieval period, what interest there was in classical learning had been disseminated through Latin texts; but as Latin lost ground even in educated circles to vernacular languages, linguistic translation became inseparable from translatio studii. To discover, to interpret, to expand and to refine "gallantry and learning" was to translate.

Marie's choice to exploit the Celtic heritage subtly implies that the position of Breton, relative to her, corresponded to that of Latin, as though she had the right to these tales by the same notion of succession that medieval translators claimed for their Roman ancestry through translatio studii. Copeland remarks:

In the Middle Ages, Latin as the established intellectual language does not represent a historically "foreign" culture to be absorbed, imitated, and appropriated [...] Latin culture is a privileged stratum within larger cultural communities, and its privilege rests on its symbolic and practical value as a force of continuity against both geographical and historical distance. Latin ties Western Europe together and links modernity with pagan and Christian antiquity. (97)

With Marie's turn from Latin to Breton as an equally legitimate source and her expectation of equal renown for the work, she cleverly assumes not only a shared status between Latin and Breton, but a shared commonality and continuity, as though the Breton texts, like the Latin ones, were not foreign but rather intrinsic to the assumed and adopted cultural heritage of the Normans.

Her declared motivations, however, raise further questions. What criteria did Marie employ in order to select from among the many lais she had heard the twelve which (as far as we know) she ended up choosing? And what precisely were these sources: the lais as sung by the minstrels, the stories that gave rise to the lais, or the events which were thought to have inspired the stories?

\footnotetext{
${ }^{4}$ "Ce nos ont nostre livre apris, /Que Grece ot de chevalerie/Le premier los et de clergie./Puis vint chevalerie a Rome/Et de la clergie la some, /Qui ore est an France venue./Des doint qu'ele i soit retenue/Et que li leus le abelisse/Tant que ja mes de France n'isse/L'enors qui s'i est arestee."
} 
Following her project through the subsequent stages of the Hermeneutic Motion will shed some light on these problems.

\section{Unequal Powers: The Conqueror Speaks for the Conquered}

The second stage of translation in Steiner's model is that of aggression. Translation by its very nature encircles and ingests its object; alterity is gone and the text is thinned, the code is broken (Steiner 314). Jerome described it as taking meaning over into one's own language just like prisoners, by right of conquest (qtd in Steiner 281).

Marie only hints as to why she chose the particular lais she translates. She starts Guigemar with the proviso, "When working with fine material, it is a matter of great concern to an author if justice is not done to it" (lines 1-2). She further explains at the beginning of Milun: "Whoever wishes to present a variety of tales must begin them in a variety of ways, and put enough thought into the way they are told that the result gives people pleasure" (lines 1-4). She sought, then, rich material and endeavoured to give it variety; perhaps she avoided tales that treated the same themes too repetitiously. However, by entering Breton territory and imposing her selection, it was she who chose the voice by which the conquered people told their stories. Robert Stein points out the inevitable consequence of a translator's selection: "any choice to speak is simultaneously a choice not to speak otherwise" (33).

The choice to translate poetry means at the outset that "translation" is a loose term. The term lai is a Celtic word thought to be related to the Irish laid "song"; it seems that the lai was a poem recited to the accompaniment of a harp or other instrument (Rohlfs 74). That it was a musical form suggests that it followed patterns dictated not only by semantics but also other stylistic constraints; likewise, the receiving language is bound by its own strictures of prosody. The transfer of poetry, therefore, comes no closer to translation than what Jakobson calls "creative transposition" (131). It is difficult to tell, from our distant vantage-point in time, much about the form and content of the Breton originals. Freeman suggests (862-5) that this was unclear even in Marie's own day because the author's ambiguousness about the precise relationship between her poems and their sources was deliberate; this was an area of silence from which Marie could produce the confrontation of two worlds, expressly leaving out "what seems essential" (865) to the genesis of the stories.

It may be, however, that the information which "seems essential" to scholars and readers today may not have been so to Marie's contemporary audience. Medieval exegetes did not trouble themselves with the consciousness, plaguing us since Schleiermacher, of reading their own history into the text; they simply made their history part of the interpretation, a dialectic condition rather than an accident of interpretation. The absence of any conflict over the process is "itself the

\footnotetext{
5 "Ki de bone matire traite, / mult li peise, se bien n'est faite."

6 "Ki divers cuntes vuelt traitier,/ diversement deit commencier/e parler si raisnablement/ que il seit plaisible a la gent."
} 
productive ground for medieval interpreters" (Copeland 61-2). As we have seen above, the concept of translatio studii conferred on medieval translators not just the power but indeed the responsibility to gloss the text, to consciously enter it and refine it. This, we must confess, is worlds away from current debates in translation theory. Whatever the approach under consideration today, it is generally the case that the priority is on how to most accurately and objectively represent the source text. Medieval translators had no such preoccupation. Rather, they were convinced that the purpose of translation was to engage their world in a dialogue with the world of the source, consciously or unconsciously importing their own story into the text's story. We force, anachronistically, a modern ethic into Marie's sphere if we expect her to credit her sources and document their transformation in the same way that we would likely do.

So what exactly did Marie translate? She uses three terms: lai, conte and aventure. Although she may not have been as careful as the modern investigator might like in delineating the three, I think that she was reasonably clear: "I will recount to you in a few words the tales which I know to be true, from which the Bretons have composed their lais" (Guigemar lines 19-21); "The adventure that you have just heard really happened — of that you may be certain; and from it was composed the lai of Bisclavret"8 (Bisclavret lines 315-317). She is quite clear that her project was to unearth the events (aventure) which gave rise to the story, or tale (conte), and to tell it as the presumed historical reality behind the traditional Breton musical poem (lai) sung or played by minstrels. These three elements, then, and not just the third one, informed her approach. The musical lais of the minstrels inspired her, but it was not these that she translated, nor did she claim that her translations were themselves lais. It was the conte that had become established around an aventure, or indeed her own conte that she built about the aventure, that she composed in French narrative verse, in the same way that the Breton minstrels had composed an entirely different genre, the lais, from the aventures and their contes. This point is crucial for our understanding of her translation project: her poems are first cousins, not direct descendants, of the lais.

As for the Breton-language originals, none are extant, and notions about their content or form remain somewhat speculative. Bernard Sergent has uncovered extensive parallels to Marie's Lais in Irish and Welsh tales, certainly more than sufficient to sustain Marie's claims to have collected most of her stories from Celtic tradition. And Constance Bullock-Davies has argued convincingly that the defining characteristic of a "Breton la peculiar to Celtic bards rather than particular cultural content (27-28). By analysis of contemporary descriptions of Celtic minstrels (Gottfried von Strassburg's Tristan und Isolt lines 3509-3631; Horn et Rimenhild lines 2830-45) and comparison with later Welsh harping techniques, Bullock-Davies suggests that such performances, either entirely instrumental or with the voice accompanying in a sort of narrative counterpoint, were extremely intricate and demanding, and their best examples were treasured at the Anglo-Norman court (23-4). If these surmises are correct, they solidify de Riquer's adamant contention that Marie made no claim to compose lais, nor is there any possibility

\footnotetext{
7 "Les contes que jo sai verais, / dunt li Bretun unt fait les lais, / vos conterai assez, briefment."

8 "L'aventure qu'avez oïe/ veraie fu, n'en dutez. mie./ De Bisclavret fu fez. li lais."
} 
that her aristocratic audience could have confused her octosyllabic French narrative poems with such a distinctive and well-known form of Celtic harping and singing $(8,15)$. The reason for some confusion regarding the term "lal" is that there was at the time no name for what Marie was doing. Baum states the problem astutely: "We can see, then, that Marie's immediate sources, the contes d'aventure, are designated by a precise and unequivocal term: lais. We remark conversely the lack of a precise term designating Marie's poems, the products of her poetic effort"9 (35). I suggest that she founded a genre, short narrative poems with a Celtic flair; and the absence of any standard designation for it left a void, one which the known and precise term lai was quick to fill. Surely it would not have done so if the original Breton lais had continued to be practiced in all their admirable and alien uniqueness. But as it was, even in Marie's day the lais incarnation as a Celtic musical genre was waning and perhaps disappearing. The great popularity of her poems, attested by a contemporary author, Denis Piramus (lines 35-48), would mean that there had to be some way to refer to them; the cumbersome "Marie's poems inspired by the stories behind the Breton lais" could not have been long in giving way to the simple designation "Marie's lais".

Only in a limited and oblique fashion does Marie refer to the contemporary incarnations: she gives attention to the titles. "These are poems acutely aware of linguistic difference, a number of them even bearing multiple titles in several languages" (Fisher 205). This is primarily because the title is the signal to Marie's audience of the "text" (in the broadest sense of the term ${ }^{10}$ ) with which they are already acquainted, the musical lai as the aristocracy of Anglo-Norman England would have heard it sung by the minstrels; and by quoting the title, usually in French but sometimes also in Breton or English, Marie links that text to ber text, which is the story behind it that she undertakes to tell. Thus, far from obscuring the connection between her translation and its origin, Marie provides an indicator which makes it explicit.

This raises questions about the linguistic situation in Marie's society. If a translation was needed for an audience unacquainted with the Celtic languages, why give the titles in Breton? Conversely, if Marie and some significant portion of the court had listened with pleasure to the Breton minstrels performing their songs in the original languages, what need was there for a translation? It seems that the lais were already disappearing in Marie's day as the art-form peculiar to a subjugated minority, but that the musical form was highly appreciated and that the essence of the stories were known to the listeners and enjoyed by them. Perhaps a modern equivalent would be English-speaking audiences attending great Italian operas, admiring the music and being acquainted with the basic plot-lines of the librettos, but, excepting a cognoscenti, unable to understand the words and needing some form of translation for the works to survive in English-speaking popular culture. Thus, the Breton titles of the lais are not simply exoticism, nor are they for an audience whose multilingualism included Celtic languages (Marie's careful inter-lingual definitions suggest

\footnotetext{
9 "On peut donc constater que les sources immédiates de Marie, les contes d'aventure, sont désignées par un terme précis et unique: lais. On constate d'autre part l'absence d'un terme précis désignant les poèmes de Marie, le résultat de son travail de poète."

${ }^{10}$ I apply the term "text" to oral poetry here because the Breton culture was an oral one, and oral cultures tend to memorize and transmit traditions with a fidelity that surprises societies dependent upon the written word (see Sergent 89).
} 
otherwise), but were intended to connect Marie's written verse to the oral poetic and musical compositions known by her audience (Harf-Lancner 13; Hoepffner 46). It would be misleading to say that Marie was naming the oral source-text of her written poem, but it is rather that she makes explicit the relationship between the story she is telling and the lai which the Bretons composed from the same story.

This connection locates the oral "text" and, by extension, the historical pre-text as Marie claims to have recovered it, in the world of Breton language and culture. Yet, at least from the perspective of later history, lais are no longer what they were when Marie started, Celtic performance art that celebrated significant events and that inspired Marie to memorialize those events in a connected but very different French genre. "In the new language the text not only is transformed in itself and in its genre but enters into networks of intertextual affiliation that create very different meanings out of even its smallest elements" (Stein 33). ${ }^{11}$ Whatever the lais had been in Breton and Welsh, among twelfth-century French authors/translators they immediately began to resemble Marie's written short narrative romance poems. Along with other French romances, lais (including many of Marie's) were translated into Old Norse and into Middle English, where they exerted a strong influence on writers as pivotal as Chaucer. ${ }^{12}$ By the beginning of the thirteenth century, it appears that the memory of the lai as a musical foreign-language performance was fading. ${ }^{13}$ That this turns out to be an act of aggression as Steiner defines it, a seizing and carrying away, is evident. That is to say, in a factual sense, apart from any conjecture about attitudes or ultimate intentions, the Breton lais became established in French literature. The second motion of Steiner's hermeneutic does not assign responsibility but describes a process. Of course, Marie could not foresee the impact of her own work nor its possible effects on Breton tradition. ${ }^{14}$

What has become of the Breton lai? It has become the lai of Marie de France, the Old French lai, the genre of French, not Celtic, poetry called the "Breton lai." Marie, surely without any

\footnotetext{
${ }^{11}$ Stein is speaking of Wace's Brut, but I believe it applies perfectly to Marie's Lais as well.

${ }^{12}$ In the thirteenth century, French lais constituted an even broader genre including more fabliaux-like stories, burlesque tales of comic obscenity which were a far cry from the courtly elegance of Marie's poems (Burgess and Busby 34-5). If what came to be known as the lais of Marie no longer resembled the intricate performances of the Breton bards, the lais of a century after her day retained little in common with hers.

${ }^{13}$ According to the anonymous lai of Tyolet, there was already forming a tradition that, as with all venerable sources of knowledge in the Middle Ages, there was a Latin repository of the Breton lais: "A la cort erent racontees,/si conme eles erent trovees; / Li preude clerc qui donc estoient/ totes escrire les fesoient;/mises estoient en latin/e en escrit em parchemin,/por ce qu'encor tel tens seroit/ que l'en volentiers les orroit./Or sont dites e racontees,/ de latin en romanz trovees;/ Bretons en firent lais plusors, / si con dient nos ancessors" (25-36: "At the court [these adventures] were recounted, just as they had been composed; the wise scholars who were present there caused them all to be written down; they were put into Latin and written on parchment, for such time as was yet to be when someone would eagerly plead to hear them. Thus they are told and recounted, composed in Romance from the Latin; the Bretons made many lais, just as our ancestors say").

Similarly, the contemporary lai de l'Espine 2-8 implies that lais were collected in written form, although the language is not reported: "les aventures trespassees/qui diversement ai contees, / nes ai pas dites sans garant;/ les estores en trai avant/ki encore sont a Carlion/ens el moustier Saint Aaron" ("the adventures that took place, which I have recounted in various ways, I have certainly not told without foundation; I am revealing the stories about them which are kept at Carlion in the monastery of Saint Aaron”). (For these lais, see O'Hara Tobin.)

${ }^{14} \mathrm{I}$ am indebted to an anonymous reviewer for underscoring this important point.
} 
clear intention of doing so, made the Breton lai an integral part of French cultural expression; and with this understanding we are already dealing with the third hermeneutic motion, incorporation.

\section{Your Memory is Mine: Normans, Bretons and the Strategy of Adoption}

Steiner describes the third motion of the translation process as incorporation. This is the movement by which the artifact, first esteemed and desired, then located and acquired, becomes assimilated into the receptor language and culture. This reception, as we have noted, has often been depicted in binary terms as either domesticated, fully naturalized so as to appear to have arisen from the target context; or foreignized, retaining the characteristics of the Other that maintain its distance, culturally and structurally, from the receiving language. A somewhat less simplistic middle ground has often been proposed: the transfer of essential meaning without insistence on foreign forms. Nevertheless, all these models presuppose what is yet to be defined, namely essential meaning and its level of inherence in form; and are almost inevitably reductionist, distorting too far the reality of "innumerable shadings of assimilation and placement" (Steiner 314).

Incorporation of a translated text constitutes an intrusion into an already defined receptor culture. Steiner warns: "The import, of meaning and form, the embodiment, is not made in or into a vacuum. The native semantic field is already crowded" (314). I suggest that there are two factors which may have provided for Marie a larger than usual space to manœuvre. The first is that AngloNorman England was already a dynamically multilingual society in which translated texts were the norm, rather than the intrusive exception. Life and literature passed in Latin, English and French, as well as areas of Danish and Celtic. The notion of a national language which embodied the ethos of the people was itself (at least to the literate class) a foreign one (Stein 24-5, 32). The smoothlyfunctioning multilingualism may have concealed, however, consciousness of linguistic and ethnic difference (Fisher 198-9), in which situation the Normans, as recent arrivals and successful invaders, were the least naturalized. England under the Normans and the Angevins was an occupied territory, dominated by a small caste of rulers whose language was French and whose primary interests were continental; the vast majority of the population was English-speaking with likely nothing more than a smattering of the language of the francophone elite (Stein 24).

The second factor arises from this potential tension. There was a certain vacuum, a culturally and semantically coded empty place in the Norman consciousness which they were looking to fill: their acceptance as rulers and citizens of England.

Contemporary sources present William's conquest of England in such a way as to disavow the fact of conquest as such. This [...] develops into a strong coherently contradictory assertion that the Normans were already English even before they arrived on the island. In historical and hagiographical texts, Norman rulers find English ancestors for themselves, and otherwise present themselves as natives rather than settlers in new territory. (Stein 25) 
Stein's remarks underscore the importance of literature in this programme, in which Marie's work played no minor role. Her collection was not simply an expression of admiration of an ancient culture, of an art-form, of an exotic world of merveilles (it was all of these), but was part of a comprehensive agenda of cultural belonging. We must remember that the Normans didn't belong in England except by right of conquest; for that matter, the Normans didn't belong in Normandy except by right of conquest: the Normans were of course the Norsemen, Scandinavian invaders. Yet they had created a myth of belonging in Normandy by adopting the French language and its culture; now in England they were seeking a process of assimilation through literature.

How much Marie consciously engineered her contribution to this plan and how much was simply her unconscious participation in the existing and seemingly self-evident order-in Bourdieu's terminology, the current doxa (see Fisher 196) cannot be known for certain. Fisher insists that "Marie is a mistress of subtlety" (203) who appropriates the burden of history and drip-feeds to the Norman court an illusory heritage of belonging. The evidence from the Lais themselves of overt propaganda is wanting, but there are no lack of instances of Marie's subtlety. I have already pointed out how Marie aligns the status of Latin and Breton to imply legitimate succession into (Norman) French. We shall now look at further ways in which she "adopts" the Breton world as her own: she refers to her sources in such a way as to suggest a personal rather than academic relationship to them; and she manipulates temporality in order to situate the twelfth-century Norman audience within the legendary Breton past.

The connection of the translator to the source text conferred authority and even independence to the translated work, and the expression of this connection was a typical trope of the medieval translator. For example, Chrétien de Troyes says: "This story that I wish to tell and narrate to you we find written in one of the books in the library of the church of my lord Saint Peter at Beauvais. From there the story was taken from which Chrétien made this romance"15 (Cligès lines 18-23). Thomas d'Angleterre asserts: "Those who narrate and tell the tale of Tristan tell it differently-I have heard various people do so. I know well enough what each says and what they have put into writing; but to judge by what I have heard, they do not follow Breri, who knew all the deeds and stories of all the kings and all the counts that had lived in Britain" (Gottfried Tristan/Thomas $338^{16}$ ). And Gottfried von Strassburg explains: "I began to search assiduously both in Romance and Latin books for the true and authentic version of Tristan such as Thomas narrates, and I was at pains to direct the poem along the right path which he had shown" (Gottfried Tristan/Thomas $43^{17}$ ). Marie, on the other hand, does not follow the pattern: "Unlike most of her contemporaries, Marie does not quote or translate, even fictitiously, the original text in which her own is rooted" (Freeman 865). Rather, she consistently employs such locutions as "Once there lived

\footnotetext{
15 "Ceste estoire trovons escrite, /Que conter vos vuel et retreire,/An un des livres de l'aumeire/Mon seignor saint Pere a Biauvez: / De la fut li contes estrez, / Don cest romanz fist Crestiiens".

${ }^{16}$ Translated by Hatto.

${ }^{17}$ Translated by Hatto.
} 
in Bretagne a baron, whom I have always heard praised highly" (Bisclavret lines 15-16); "I believe that Guigemar spent a year and a half with her" (Guigemar lines 535-6); "In Bretagne there were four barons, but I don't know their names" (Chaitivel lines 33-4); "I shall tell you the tale of a very old Breton lai, and the whole story behind it, which is the truth as I understand it" (Eliduc lines 1-4). ${ }^{18}$ There is a continual intimation that the narrator not only personally heard the tales but also shares a heritage with the places and people in them. ${ }^{19}$ Since the frame-narrator is explicitly Marie the author, this gives more than verisimilitude to the stories; it insists on a personal connection to them, the unarticulated and unproven idea that the national memory belongs to her and to her people. She promotes an assumption that to turn to the Breton tales for her sources is not to turn outside of her own cultural space.

The articulation of this personal connection to the sources using present and perfect tenses implies a temporal connection of the past to the present. As Steiner says, "Remembrance is always now" (140). More particularly, Marie skillfully uses narrative to construct temporal blurring. In Bisclavret, one of the characters exclaims, "Many a wonder have we seen that has taken place in Britain!" (lines 259-260), ${ }^{20}$ implying that the world of miracles existed in the speaker's past and still bore upon his present. This allows the readers to imagine that they share a present co-temporality with the speaker and are thus permitted to adopt his marvelous past as their own as well. This technique is even more subtle in the story of Yonec. Marie begins by saying that it took place in Wales "in days of old" ("jadis", line 11). Yet the female protagonist, in a soliloquy within the story, longs for the "days of old" ("jadis", line 96) when wonders used to take place and knights would rescue desperate maidens. It is as if Sir Lancelot were longing to live in the days of King Arthur! I suggest that by representing the readers' own distant past as the past in the stories, she establishes the readers' present as the present of the stories and inserts her audience into the "now" of the narrative, allowing them to absorb the setting of the tales as their own. More than master storytelling, which it certainly is, it is co-opting the memory of the Bretons for the Norman agenda of belonging.

By this triple thrust of paralleling the tales with the continuity of the Latin heritage, personalizing the sources and connecting the Breton past to the Norman present, Marie does not even need to manage issues of foreignization, domestication or imitation. Her treatment of the Breton elements such as the supernatural, attitudes toward sex and marriage, the place of love, even the justice of murder, could have been handled either as alterities striking the reader with their exotic otherness, or as assimilated features stripped of their foreignness and grafted seamlessly into AngloNorman life, or finally as foreign elements retained but also explained or recast so that their original sense is transmitted but their incoherence is effaced. Marie does none of the three. She imports the

\footnotetext{
18 "En Bretaigne maneit uns ber,/ merveille l'ai oï loër"; "Ceo m'est a vis, an e demi/fu Guigemar ensemble od li”; "En Bretaigne ot quatre baruns, / mes jeo ne sai numer lur nuns"; "D'un mult anciën lai Bretun/le cunte e tute la raisun/vus dirai, si cum jeo entent/la verité mun esciënt'.

19 "Who is this author", marvel Burgess and Busby (8-9), "who sprinkles the prologues and epilogues so liberally with verbs in the first person and even intervenes on occasion to make comments within the tales?"

20 "Meinte merveille avum veüe/ ki en Bretaigne est avenue."
} 
strange, neither signalling it as strange nor naturalizing it, but accepting its strangeness as natural, as though it belonged alongside the other elements which she freely exploits such as biblical, classical, courtly and feudal motifs and values. Thus, she neither takes away from the strangeness, what is "theirs", nor stretches out of shape the normal, what is "ours". By positing an intrinsic continuity between Breton and Norman, by inserting herself into the heritage and the time of the tales, by positioning the source elements together but individually intact, she performs a translating action that is both methodological and ethical, an action which I am calling adoption: Theirs is Ours.

\section{The Afterlife of the Bretons: qu'um nel deüst pas obliër}

The fourth and final stage of the translation process in Steiner's model is that of restitution: enlarging and contributing to the status and understanding of the source text. Translation poses a danger of identity consuming or being consumed, of depleting the other irreparably or of being unable to absorb but only to mimic the other. At some point in the process, translation creates an imbalance: the translator takes away something that belonged by right to the source, and imports it into a place where space must be made for it. That is why the movement of restitution, which maintains equilibrium, is vital (Steiner 316). Although this is an ethical transaction, it is less about the feelings or intentions of the parties involved than it is an inherent characteristic of translation. Balance will never be perfect; there are always gains and losses, some of which may cross the line in terms of the ethical responsibility of translation. Steiner's point is that it is in the overall examination of a translation's movement through the four stages and especially in the assessment of its fourth stage, the level of reciprocity and compensation, that a translation's fidelity to the source can be evaluated (318).

The need of the Anglo-Normans for a link, real or imagined, to England's past can be rightly seen as a spoliation of the Breton heritage (Fisher 202). Conversely, the adoption of that heritage is an attribution of value-all the more striking when we ask ourselves how many invaders have striven to adopt the culture of the colonized. To confess need for the other is potentially exploitative but also potentially humbling. This aspect of restitution - the literature of the invader valorizing the culture of the conquered, the willingness of the Normans to adopt with a sort of pride the heritage of the insular Celts - may have played its own small part in the development of British identity. "Had Normanitas been more vehement," Fisher (199) insists, "today's inhabitants of the British Isles might all consider themselves Norman-French rather than English, Welsh, Scottish, or Irish. As it is, the insular identities won out." While the intent of Marie's project (about which intent we can do no more than speculate) may have been to appropriate Breton tradition for the benefit of the francophone Normans, the actual result seems to have contributed rather to a strengthening and a durability of Celtic self-awareness.

By not simply translating the lais from their Breton form, but making her project an archaeological one, digging back to the origins of the tales, Marie seems to feel a consciousness of assigning credibility to the Breton heritage. She often insists on the "truth" of her findings (Guigemar 
line 19; Equitan line 317; Bisclavret lines 315-316; Les Dous Amanz line 253; Chievrefueil lines 3, 117; Eliduc lines 3-4) at a time when the minstrels were criticized for exaggeration and distortion (Hoepffner 38-9). We do not know that Marie believed, say, in the existence of werewolves (although she makes no effort to suggest that she did not), but she maintains that she believed in the verification of the lineage of the tales, from the days of their origins in the far-distant past to the singing of the lais which, as she tells us, she herself had heard. Though Marie's contemporaries shared her passion for uncovering the most accurate versions of the tales, they did not necessarily share her respect for or pleasure in the lais that had developed from them (e.g. Prologue lines 33-39; Guigemar lines 883-6).

Marie declared that one of her motivations in undertaking her project was to attribute value to the Breton stories and to preserve them from being lost and forgotten (Prologue lines 33-40). It is tempting to think of Marie's translation as ethnographic. After all, she was concerned that a nation's stories, embodied in an admired but threatened form, might be doomed to disappear, and so set for herself the task of "remembering". Kinoshita and McCracken suggest that with her choice of the Breton lais, Marie "emerges as an anthropologist avant la lettre" (26). I believe that this is a fascinating lens through which to explore the connections between Marie's avowed goals and her actual literary constructs, and it may help us to understand her motivations in the late twelfth-century AngloNorman context. However, it is an optic which, I suggest, must be applied with great caution. I suspect that the concept of anthropology as it exists today could scarcely have been possible before the Enlightenment. The preservation of the memory of events or legends, the rescue of wonderful and entertaining tales from oblivion, must not be confused with the recording, as objectively as possible, traditions of a people as perceived by those people or as enshrined within their own culture. Anthropology has its own peculiar challenges of objectivity and interference, with none of which Marie wrestled. She had no qualms about resetting, reworking and recreating the lais. Shirin Azizeh Khanmohamadi, who likens the Lais to "an early form of salvage anthropology: the salvaging of native materials against the losses born of colonial incursion" (51), nevertheless astutely nuances such a view:

Marie links her interest to that of Breton barons of yore: she, like them, wants to memorialize a precious Breton past lest it be forgotten. But in so doing, Marie has seamlessly overlaid Breton poetic production with her own, eliding the large passage of time and space that separate the supposedly shared investments of ancient Breton barons and a present-day French woman living and writing her Breton lais in England. (50)

Imposing upon Marie an ethic of modern scholarship is a critical mistake in interpreting Marie as a medieval writer and translator. It was rather her task, as she saw it, to uncover the fascinating memories of the Celtic communities that had inspired the lais, to draw them out of their original languages and to reconceive them in French, thereby "contributing more to their meaning" (Prologue line 16) by enriching their details with all the accoutrements of her own culture and understanding. 
I argued above that Marie did not preserve the artistic genre of the Breton lai and apparently made no attempt to do so. The point is not a moot one. If Marie translated, not the Breton lais, but the original stories that gave rise to those lais, as well as she could reconstruct them, this sheds important insight into her task of "remembering". It is not the preservation of an art form nor even of the tales embodied in that form that was Marie's task, but (certain selected) constituents of a culture, its peculiar stories and distinctive characteristics, which she transported bodily and at times almost incongruously into Old French octosyllables and into her world of Norman feudality, Christian morality and romantic chivalry. The new setting is the element that confuses the issue. There are thus several aspects of Marie's work that cannot be reconciled with a modern view of anthropology. She did not attempt to preserve cultural artifacts intact but transferred them (in true Norman fashion) into her own world; she did not (necessarily) value the stories for their own sake, nor for the sake of cultural preservation, but for their nostalgic charm and their entertainment value; and she implies throughout her project that the traditions of the Bretons are legitimately hers to exploit. None of this is because she was a poor anthropologist or a poor interpreter but because she was a great medieval writer and translator. If we can succeed in viewing her in that context, understanding her as a sort of pre-modern "salvage anthropologist" is a legitimate acknowledgement of what appears to be her honest desire to rescue the tales of a conquered nation from obliteration.

In Marie's day and beyond, the "Breton lais" continued as a French literary genre but at times without any specifically Breton content. Therefore, in what manner the genre continued to contribute to the memory of the Breton people and their culture as represented in the old lais is problematic. Marie certainly added to the keen interest in the "matter of Britain" celebrated in the literature of the day. The heterogeneity of her stories, the translation strategy of adoption which I maintain is her great strength and a key reason for the lasting fascination of her work, made her more difficult to appreciate in her time; her untamed assortment of Breton practices, feudal expectations and Christian morality was "startling, and evidence suggests that audiences were unsure what to make of it" (Fisher 210). Still, while manuscript copies of her Lais are few and reworkings of her tales in medieval literature less than abundant, her project took its place among those of the greatest writers of her day (a place which it has not ceded even after more than eight centuries), evoking interest in the Breton world, the odd mix of chivalry and faith and barbarism, Arthur and his knights, quests, true love, and the wonders of the supernatural. The Anglo-Norman court loved her Lais, which seemed to offend her contemporary Denis Piramus primarily because he contested that they were pas del tut verais (line 38), not at all true. Over the next century and a half, it is clear that her works remained influential. French short courtly romances in verse became known generally as "Breton lais" regardless of the stories' origins (Pickens 343), an attribution which extended to later French, Middle English and even Norse versions (see Gœres; Huot; Rumble). The imagery of intertwined lovers like a honeysuckle vine encircling a tree and the imagery of the nightingale in Chaucer's Troilus and Criseyde must be drawn from Marie's Chievrefueil and Aüstic (Wilcockson, qtd in Huot 192). Huot also traces a clear imprint of Marie in Renaut's Galeran de Bretagne, based on Fraisne and influenced by other lais (193-5) and in Renart le Contrefait, which includes modified versions of 
Aïstic and Bisclavret and influences from Yonec and Guigemar (195-199), as well as in the Roman de Perceforest, which draws on Yonec and perhaps a little on Milun (199-202). While later uses of Marie preferred a somewhat "expurgated version" (Huot 202), where sex and violence have been hushed to suit the sensibilities of Christian morality, I attribute to Marie's strategy of incorporation through adoption the preservation of more primitive elements that allow a closer grasp, and perhaps a better memorial, of their Breton models.

If we are to speculate about intentions, we have no word on the subject but Marie's own. Her desire, as she described it, was to tell her stories well, to gain renown for herself, and to save from oblivion tales that had been treasured by the people of old and that, she feared, were in danger of being forgotten. She seems to have attained all three of these goals. What Marie accomplished was a work of remarkable creative power. Her love of the stories that had impacted her aesthetic sense, and her re-embodiment of those stories within the felicity of her narrative and poetic powers, seems to have drawn out a corresponding enthusiasm from her audience. In invading and appropriating the Breton lais she made a transformation which would re-embody the Breton original in a new form and would leave its mark on French literature for as yet uncounted centuries. If not only the performance of the tales but the tales themselves were at risk of disappearing, Marie did more than rescue them from oblivion: she set them centre-stage in the traditions of European literature. Steiner observes that in such a case 'language was 'new'; or, more accurately, the poet, the chronicler, the philosopher gave to human behaviour and to the current of mental experience an unprecedented "second life"' (23). That second life was a tribute and turned out to be an enduring memorial to the Breton culture. There was, however, a cost: the assumption, whether conscious or not, that the Breton heritage could be adopted by the francophone Normans.

Perhaps the greatest compensation that can be made to the source texts is the delight that Marie conveys to the reader. A multitude of political, social, practical or artistic motivations can be argued for her undertaking the enormous task of rendering the stories of the lais in French verse (Prologue line 42), all of which undoubtedly contribute some insight into the question; but we would do well not to bury under all of these the joy of a writer in a great story. "The people of old made a lai about their love and happiness, and I, who have put it into writing, take great pleasure in the telling of it", ${ }^{21}$ says Marie at the end of Milun (lines 531-4). Harf-Lancner comments: “The storyteller's pleasure: it is only this that can inspire pleasure in the hearer or the reader" 22 (19). Though, as Hoepffner observes, the lais are briefer, lesser in stylistic elegance and literary and psychological depth than the romans of Chrétien de Troyes or Thomas d'Angleterre, they are fresh, unaffected, and charming (166). Popularity and reader appreciation should not constitute the entire yardstick of literary criticism, but they surely say much about a translation's tribute to its sources.

\footnotetext{
21 "De lur amur e de lur bien/firent un lai li ancïen; / jeo ki l'ai mis en escrit/ el recunter mult me delit."

22 "Le plaisir du conteur : lui seul peut appeler le plaisir de l'auditeur ou du lecteur."
} 


\section{Conclusion}

Marie de France's Lais present an intriguing set of problems in terms of translation analysis, some peculiar to her project and others common to translation in general. With no extant source texts, with scarcely analogous texts of the source genre and language, any discussion of the nature of the semantic or formal transformation of the lais from source to target is tentative at best. Equally lacking are any commentaries on Marie's mental or methodological processes as she accomplished her translation, save those morsels which she herself provides, which, as part of the text itself and not a meta-text, may be as much narrative technique as self-revelation. As with almost every translation, all that presents itself is the final artifact. Any approach, then, which attempts simply to locate the work on the spectrum of domestication versus foreignization, or literal versus paraphrastic, ends up in conjecture. I have found Steiner's model of the Hermeneutic Motion illuminating in probing the issues of the translation of the Lais since it depends on following the existing artifact itself, Marie's text, through its four stages from initial motivation through acquisition and incorporation to restitution, an analysis which is informed by both internal and external features. These features provide a greater insight into her choice of material, her ingression into her sources, her appropriation of them to the Anglo-Norman context, and the lasting impact, in terms both of loss and of tribute, upon the heritage of the Bretons; in short, a deeper appreciation of the complexity and subtlety of Marie's project, by which she welcomes the Breton lais into her society not by importation nor by naturalization but by the relationship of adoption, claiming the miracles of bygone days and the customs of the ancients in all their strangeness as belonging to her and her nation by an assumed succession. This does not finally resolve the issue of the exploitation of memory through translation, nor does it ethically valorize the assumption and articulation of the culture of the conquered by the conquerors; but it does shed light on the dynamic and creative forces of peoples and heritages in contact, and it underscores the capacity of translation to not only transmit texts interlingually but to both denigrate and enhance, to appropriate, and perhaps ultimately to immortalize in a new art form, what might otherwise slip forever from human knowledge. 


\section{REFERENCES}

Asad, Talal. "The Concept of Cultural Translation in British Social Anthropology." Writing Culture. Eds. James E. Clifford and George Marcus. Berkeley: University of California Press, 1986. 141-164. Print.

Baum, Richard. Recherches sur les oewvres attribuées à Marie de France. Heidelberg: Universitätsverlag, 1968. Print.

Bullock-Davies, Constance. “The Form of the Breton Lay.” Medium Aevum. 42. (1973): 18-31. Web.

Burgess, Glyn S. and Keith Busby. "Introduction." The Lais of Marie de France. By Marie de France. c. 1165. Trans. Glyn S. Burgess and Keith Busby. 2nd ed. London: Penguin, 1999. 7-36. Print.

Chrétien de Troyes. Cligès. c. 1180. Ed. Wendelin Fœrster. Trans. Ingrid Kasten. Berlin: Walter de Gruyter, 2006. Web.

Copeland, Rita. Rhetoric, Hermeneutics, and Translation in the Middle Ages: Academic Traditions and Vernacular Texts. New York: Cambridge, 1991. Print.

De Riquer, Martín. “La aventure, el lai y el conte en Maria de Francia.” Filología Romanza 2 (1955): 1-19. Print.

Denis Piramus. La Vie seint Edmund le rei. An Anglo-Norman Poet of the Twelfth Century. c. 1180. Ed. Florence Leftwich Ravenel. Philadelphia: John C. Winston, 1906. Web.

Fisher, Marianne. "Culture, Ethnicity, and Assimilation in Anglo-Norman Britain: The Evidence from Marie de France’s Lais.” Exemplaria 24. 3 (2012): 195-213. Web.

Freeman, Michelle A. "Marie de France's Poetics of Silence: The Implications for a Feminine Translatio.” PMLA 99. 5 (1984): 860-883. Web.

Gœres, Erin Michelle. "Sounds of Silence: The Translation of Women's Voices from Marie de France to the Old Norse Strengleikar." JEGP, Journal of English and Germanic Philology 113. 3 (2014): 279-307. Web.

Gottfried von Strassburg. "Tristan und Isolt." c. 1210. Dichtungen des Deutschen Mittelalters 2. Ed. H. F. Massmann. Leipzig: G. J. Göschen’sche, 1843. Web.

—. Tristan, with the 'Tristan' of Thomas. Gottfried c. 1210; Thomas c.1160. Trans. A. T. Hatto. London: Penguin, 2004. Print. 
Harf-Lancner, Laurence. "Introduction." Lais de Marie de France. By Marie de France. c. 1165. Ed. Karl Warnke. Trad. Laurence Harf-Lancner. Paris: Le Livre de Poche, 1990. 7-19. Print.

Hœpffner, Ernest. Les Lais de Marie de France. 1935. Paris: Nizet, 1971. Print.

Horn et Rimenhild. c. 1170. Ed. Francisque Michel. Paris: Maulde et Renou, 1845. Web.

Huot, Sylvia. "The Afterlife of a Twelfth-Century Poet: Marie de France in the Later Middle Ages." 'Li Premerains Vers': Essays in Honour of Keith Busby. Eds. Logan E. Whalen and Catherine M. Jones. Amsterdam: Rodopi, 2011. 191-203. Web.

Jakobson, Roman. “On Linguistic Aspects of Translation.” 1959. The Translation Studies Reader. Ed. L. Venuti. 3rd ed. New York: Routledge, 2012. 126-131. Print.

Khanmohamadi, Shirin Azizeh. "Salvage Anthropology and Displaced Mourning in the Lais of Marie de France." Arthuriana 21. 3 (2011): 49-69. Web.

Kinoshita, Sharon and Peggy McCracken. Marie de France: A Critical Companion. Cambridge: Brewer, 2012. Print.

Marie de France. Lais de Marie de France. c. 1165. Ed. Karl Warnke. Trad. Laurence Harf-Lancner. Paris: Le Livre de Poche, 1990. Print.

O’Hara Tobin, Prudence Mary. Les lais anonymes des XXe et XIIe siècles. Genève: Droz, 1976. Print.

Paris, Gaston. Compte rendu [review] of Marie de France, L'Espurgatoire seint Patriz of Marie de France: An Old French Poem of the Twelfth Century. Ed. Thomas Atkinson Jenkins. Philadelphia: Alfred J. Ferris, 1894. Romania XXIV (1895): 290-295. Web.

Pickens, Rupert T. "BnF, nouv. acq. fr. 1104: Marie de France and 'Lays de Bretagne"'. Li Premerains Vers': Essays in Honour of Keith Busby. Eds. Logan E. Whalen and Catherine M. Jones. Amsterdam: Rodopi, 2011. 341-356. Web.

Rohlfs, Gerhard. From Vulgar Latin to Old French: An Introduction to the Study of the Old French Language. Trans. Vincent Almazan and Lilian McCarthy. Detroit: Wayne State University Press, 1970. Print.

Rumble, Thomas C. Introduction. The Breton Lays in Middle English. Ed. Thomas C. Rumble. Detroit: Wayne State UP, 1965. xiii-xxx. Print. 
TranscUlturAl, vol. 8.1 (2016), 17-37.

http://ejournals.library.ualberta.ca/index.php/TC

Schleiermacher, Friedrich. "On the different methods of translating." 1813. Trans. Susan Bernofsky. The Translation Studies Reader. Ed. L. Venuti. 3rd ed. New York: Routledge, 2012. 43-63. Print.

Sergent, Bernard. L’Origine celtique des Lais de Marie de France. Genève: Droz, 2014. Print.

Stein, Robert M. "Multilingualism." Middle English. Ed. Paul Strohm. Oxford: Oxford University Press, 2007. 23-37. Web.

Steiner, George. After Babel: Aspects of Language and Translation. 2nd ed. New York and London: Oxford University Press, 1992. Print.

Stierle, Karlheinz. "Translatio Studii and Renaissance: From Vertical to Horizontal Translation." The Translatability of Cultures: Figurations of the Space Between. Eds. Sanford Budick and Wolfgang Iser. Stanford, California: Stanford University Press, 1996. 55-67. Web.

Venuti, Lawrence. The Translator's Invisibility: A History of Translation. London and New York: Routledge, 1995. Web.

Wace. Le Roman de Brut: The French Book of Brutus. 1155. Trans. Arthur Wayne Glowka. Tempe, Arizona: Arizona Center for Medieval and Renaissance Studies, 2005. Print.

Warren, Michelle R. "Translation.” Middle English. Ed. Paul Strohm. Oxford: Oxford University Press, 2007. 51-67. Web. 